\title{
Introduction - Theory and History of Historiography: from the Linguistic Turn to the Ethical-Political Turn ${ }^{*}$
}

\author{
Marcelo de Mello Rangel \\ mmellorangel@yahoo.com.br \\ Associated Professor \\ Universidade Federal de Ouro Preto \\ Rua do Seminário, s/n - Centro \\ 35420-000 - Mariana - MG \\ Brasil
}

Valdei Lopes de Araujo

valdei354@gmail.com

Associated Professor

Universidade Federal de Ouro Preto

Rua do Seminário, s/n - Centro

35420-000 - Mariana - MG

Brasil

\footnotetext{
* This text is a partial result of research projects funded by the Conselho Nacional de Desenvolvimento Científico e Tecnológico (National Council for Scientific and Technological Development) - CNPq and by Fundação de Amparo à Pesquisa do estado de Minas Gerais (Fapemig; Minas Gerais Research Support Foundation), the former, by the support program to emerging groups that funds the collective research Project "Varieties of Historic Discourse" within the Núcleo de Estudos em História da Historiografia e Modernidade (Center for the Study of History and Historiography of Modernity) - NEHM.
} 
This dossier brings together lectures presented at the $6^{\text {th }}$ Brazilian Seminar of History and Historiography (SNHH), which took place in 2012 in the city of Mariana, discussing the problem of the linguistic turn. The reader will have access to texts authored by Guilhermo Zermeño Padilla (Colegio de México), Rogério Forastieri da Silva (Colégio Etapa-SP), Temístocles Cezar (Universidade Federal do Rio Grande do Sul - UFRGS) and Sérgio Campos Matos (Universidade de Lisboa). The choice of the theme was due mainly to the 40 years of the publication of Hayden White's book Metahistory: The Historical Imagination in the $19^{\text {th }}$ Century, to be celebrated one year after the $6^{\text {th }} \mathrm{SNHH}$, in 2013.

The discussions engaged in during the event and the texts published here problematize and help us to reflect about the linguistic turn and the questioning of the relationship between identity, thought, and language, particularly within historiography. From our discussions, and mainly the texts composing this volume, the $18^{\text {th }}$ and $19^{\text {th }}$ centuries can be approached as the origin both of the understanding questioned by the linguistic turn - according to which thought produces privileged enunciations in relation to reality - and of fundamental elements to the structuring of its criticism.

It should also be highlighted that the most traditional concept of linguistic turn proposes it as a recent phenomenon originated in the decades following the Second World War. Here, we prefer to adopt the view according to which the linguistic turn is a broader historical-cultural displacement to be defined around the classical Foucaultian description of the crisis of representation, that is, the 3.34 progressive split between words and things whose turning point was the $18^{\text {th }}$ century (FOUCAULT 1999). This broader definition, however, does not deny the existence and the relevance of approaches that address the phenomenon as a decisive event/process in relation to recent intellectual history.

Thus, it is our aim to think about the conditions of possibility of the linguistic turn, which took shape some centuries earlier, namely the broad perception of the "growing acceleration of transformations within time," inherent to modernity, enabling the questioning of the traditional role of historiography" and, in a second moment, the radical consideration of the epistemological problem of "partiality" and point of view. Complementarily, we can bring forth and understand two specific traditions within the linguistic turn, finally aiming to reflect on the possible effects of this epistemological shift.

\section{The Centrality of the Problem of Language in the Origin of Modernity}

On the conditions of possibility for the actualization of the linguistic turn, we have, in the first place, the constitution of a particular experience of time, deeply accelerated, to use Reinhart Koselleck's term, or the loss of immediacy of meanings and senses able to direct men and promote the stability of human selfreference (KOSELLECK 2006). Thus, both traditional and recent concepts, such as God, State, Absolutism, Parliament, Constitution, History, Nature, Science, Empire, Nation, Commerce, Anarchy, Republic, Liberalism, Communism, Capitalism or Socialism compete for a position of hegemony. In addition, a series of historical happenings and processes, such as the Industrial Revolution, the 
Independence of the United States, the French Revolution and the Napoleonic Expansion, and the Independence of the Spanish and Portuguese colonies in the Americas, among others, were experienced and produced as unheard of realities for which there were no satisfactory answers within the traditional repertoire (ARAUJO 2008; 2009; 2011; LYNCH 2014; RANGEL 2014).

The senses available were contested and had to compete for space along with others that started to appear throughout and insofar as the self-reference of 'modernity' took shape. Paradoxically, this process that aimed to reestablish a maximally stable order ended up stimulating critiques and oppositions, thus intensifying this acceleration. Finally, a radical differentiation of historical conjunctures started to occur and, at the same time, modern identity was being produced, not independently, of course, of metanarratives that ensured the present and future totalization of what had supposedly been left behind (GUMBRECHT 1998).

This accelerated movement of "History" was responsible for the constitution of a specific aspect concerning the actualization of the condition of its temporalization - the actualization of the tension between 'space of experience' and 'horizon of expectation' - resulting in a meaningful diminishing of the 'space of experience'. This means that in face of maximally unheard of conjunctures men behaved variously and dynamically so as to intensify and produce realities that significantly differentiated themselves. The result of this profoundly accelerated temporal experience was the loss by men of a great deal of confidence in their pasts and their power of rearticulating and reorganizing the present.

It is then that the first condition of possibility for the linguistic turn emerges - the radical contestation of history as magistra vitae and, accordingly, the possibility of putting forth the question - what is the role of history ('historiography')? This question will enable, on its turn, the emergence of philosophies of history and, then, historicisms. It is important, then, to highlight that the phrase "history as magistra vitae" is used as a metonymy for a certain way of experiencing historical events that matured throughout the centuries of Western history, which crossed different shapes and models, but always pointed to relatively stable elements in the experiential level.

Philosophers of history and historicists have organized themselves to answer this question about the conditions of possibility of historical knowledge and its relevance to men. The former offer the explanation that 'History' is realized necessarily from certain senses, in spite of men and realizing their perfectibility - the logic of progress. 'Historiography' starts to be constituted from the responsibility of evidencing the fundamental senses to 'History' with the aim of accelerating its realization and thus diminishing the suffering of men in search for happiness. We have the possibility of overcoming the problem posed to 'historiography' by the radical acceleration of time, so that, if on the one hand we have a process of significant and unstopping differentiation of 'History', therefore of succeeding conjunctures; on the other hand we find the possibility of casting a deeper look into 'History', realizing and shedding light on its intrinsic meanings, which are actually unchanging and teleological. 
However, insofar as the philosophers of history liberated these senses, 'History', more properly, did not allow them to verify their exceptionality, that is, within this accelerated rhythm, these senses were contested so that they did not gather enough strength to determine the reality and to verify its privileged constitution. The immediate result was the contestation of philosophies of history, mainly by historicists, less due to their background understanding of the temporalization of 'History' than to the necessary procedures to the observation and the rendering explicit of these senses. It is a type of methodological moment that is profoundly theoretical, dedicated to the discussion and the production of ideal conditions of possibility for the observation and evidencing of determinations proper to 'History', those which, once availed and intensified, would be able to accelerate the realization of the very historical process, then avoiding suffering. The problem is that modernity also does not allow historicist enunciations to stabilize it, unless in a first moment and in the way aimed at, so that they also started to be contested.

We have, then, the emergence of the second condition of possibility to the constitution of the linguistic turn, more properly epistemological. From the radical acceleration of time, typical of modernity, arises the questioning of history represented and, yet, the possibility of a radical questioning of its function, a process that will be vigorously reedited within the linguistic turn, and, more, it will be crucial to the emergence of the philosophies of history and historicisms, which, on their turn, will end up enabling (and liberating) the significant questioning 3.36 of each and every privileged relationship between language and reality, which is a primary problem within the traditions converging in the linguistic turn. From the philosophies of history, we have a first answer that has not been absorbed by 'History', which guided historicists in developing their reflections and methodologies. Historicists suggested that the problem of philosophies of history was not their diagnosis of 'History', but actually the way or form proposed, which was profoundly arbitrary and 'subjective'. They would not have been able to thematize with due attention and care the basic position of men in general, including men of science, their positioning within a transcendental and, therefore, determinant world. In other words, historicists evidenced (and liberated) a radical problem - the relationship of intimacy between enunciations, including historiographical ones, and the worlds from which they became possible. For such, there would be the possibility of constituting a set of methods and protocols able to open up a controlled access to historical reality, thus ensuring the possibility of evidencing senses proper to the necessary realization of 'History' as reality-process, granting humanity the appropriate conditions to progress and to diminish suffering.

However, since the senses liberated by historicists did not prove crucial to 'History' as well (because they did not occupy, at least in a first moment, the condition of immediacy), we have the emergence of the following problems: (1) whether historical reality has no sense(s), (2) or it has, but not even the more sophisticated methods and protocols are able to offer the ideal conditions of possibility for historians to evidence it (or them). Ultimately, it is the 'second-order observer' crisis (GUMBRECHT 1998; 1999). 
Thus, historicisms themselves liberate, including due to their theoretical strength and sophisticated sensibility, the second condition of possibility mentioned above, crucial to the constitution of the linguistic turn, namely the epistemological problem of the impossibility of production of any exclusive enunciation about reality, a movement that, on its turn, has intensified the questioning about the function (or the need) of history throughout the $20^{\text {th }}$ century. Therefore, modernity and its philosophies of history and historicisms constitute two possible conditions to the linguistic turn: (1) the acceleration of time that destabilizes the almost tangible immediacy of history accumulated by history as magistra vitae and, therefore, enables the question - to what is history for? - and (2) the very questioning about each and every possibility of constituting criteria of selection of privileged enunciations in relation to reality, including (and, in our case, specially) within historiography.

Therefore, two important conditions to the constitution of the linguistic turn are set: one, historical-structural, is the radical acceleration of time typical of modernity, and the following questioning of the need of history. And, afterwards, the second, historical-epistemological, is the thematizing of what could be named the impossibility of any privileged access to reality. Thus, the $20^{\text {th }}$ century inherits this epistemological challenge, which has been made available throughout the $19^{\text {th }}$ century and faced by at least two different traditions - the phenomenological-hermeneutic and the neo-historicist (or post-modern). In other words, it can be said that the linguistic turn is constituted (and intensified) from these two traditions.

\section{Two Traditions between Convergence and Dispersion}

The phenomenological-hermeneutic tradition is more precisely associated to Husserl and Heidegger. After them, it follows with historians and literary theorists such as Gadamer, Paul Ricoeur, Koselleck and Gumbrecht and has influenced philosophers and historians like Walter Benjamin, Jörn Rüsen and François Hartog. In spite of the profound differences among them, this tradition deals with the idea that each and every thought and action within the present is determined by the relationship of intimacy with pasts and futures, which are constituted as transcendental points of determination that guide and determine each present. Therefore, there is the eventual intensification of the fundamental premise of the linguistic turn, that there is no possibility of a construction of privileged enunciations in relation to reality or even objective enunciations in the sense of being directly available in front of us, according to the German word Gegenständlichkeit.

The neo-historicist or post-modern tradition is more precisely linked to philosophers, historians and literary theorists as Wittgenstein, Roland Barthes, Lyotard, Jean Baudrillard, Hayden White, Frank Ankersmit, Keith Jenkins, Stephen Greenblatt among others, and its basic understanding is that there is a radical autonomy of the present in relation to the past and, more, that men within the present reconstitute a certain organization, only provisional, of 
'History'. ${ }^{1}$ In other words, its perception of time is that it is transitional, that it is radically and incessantly differentiated, thus intensifying, in this sense, the understanding of time proper to the 'historicist chronotope', to use a term that is dear to Gumbrecht and, including for this reason, they are called neo-historicists (GUMBRECHT 1999; 1998; ARAUJO 2006a; RANGEL 2010; RANGEL; RODRIGUES 2012). Within this temporal perception, historical thinking is understood as the ideal ambit (or strategy) for the constitution of ideal enunciations to temporal stabilization (even if provisional). In the end, in spite of distinctions concerning the phenomenological-hermeneutic tradition, this fundamental determination of the linguistic turn is intensified - that there are no privileged (objective, in the sense advanced above) enunciations concerning reality.

To be even more precise in relation to the first tradition, phenomenological-hermeneutic, the following basic temporal structure can be commented on: man is the very structure of the constitution and temporalization of 'History'. From him it is established and differentiated through a tension between a certain protagonist past effective in the present, other obscured pasts that continue to compete for protagonist roles within (present) 'History', and finally its own reception (or lack of) in the present. According to Heidegger, for instance, man is a specific structure, Dasein, which is determined by its 'there' and its 'ability-to-be' which it also is. The there, or yet the 'world', means, more appropriately, a set of established meanings and senses from which Dasein is oriented, and the ability-to-be is the necessity of projecting or even willing 3.38 something more than what is at least evidently offered by a certain world. Thus, it is from the tension between there and ability-to-be that 'History' or even time is temporalized or differentiated and established (HEIDEGGER 2008, §§ 72-77; ARAUJO 2013; CASANOVA 2013). ${ }^{2}$

It is easy to perceive the insufficiency of the disciplinary and specialized definition of what Heidegger calls historic. Thus, its distinction between historiographical, a type of approach of phenomena in the world of life that arises from the presupposition of the centrality of temporality (Dasein) as the fundamental structure of humankind and the historiological, what we know as the science of history in its more traditional sense. This awareness may help us to thaw historic representations from the investigation of oscillation between proper and improper history, opening the way to the acceptance and evidencing of certain pasts more or less obscured within the present. That would enable the reorganization of the triad - past, present and future -from historiography. These two adjectives ('proper' and 'improper') do not point to unequal values in Heidegger, but to two existential forms (originally complementary) of relating with historical time. The improper is determined by the human necessity of addressing the surrounding world reducing it to reachable objects of use from a specific sense or set of

\footnotetext{
${ }^{1}$ In relation to this scheme that points to the existence of two great traditions within the linguistic turn, as well as associates certain authors to one group or the other, it is a didactic organization to enable us to acknowledge the differences within each of these traditions and, more, the very possibility of questioning the relationship between author and tradition sketched by us or even the rearrangement of the list presented. 2 About this movement of temporalization of time or 'History' from the Dasein, see the discussion about death and birth in Chapter Five of the second part of Being and Time.
} 
senses, then objectifying also present and future which are no longer experienced as an environment. For short, what is there in the improper way is the ongoing repetition of a protagonist sense that renders the movement of differentiation of 'History' (or, yet, its thawing) unlikely. Thus, recovering the ecological dimension of historical time, for Heidegger its primary dimension, may reveal historicity itself. Here, the dimensions of past, present and future are interchangeable and modalizable, valuing simultaneity instead of succession.

What has been called historiography until today is the reduction of investigation and of its awareness to the improper dimension of historicity. Thus, the history of historiography would no longer be a kind of auxiliary of history as science to become a global approach of humankind with a particular attention to the existential structures of temporality. In addition to the cognitive gain, we could do justice to the huge expansion of objects and phenomena that the community has been investigating. Then, traditional, specialized approaches, such as Intellectual History, could be translated into this new universe. This shift arises from the acceptance that all historiography, as historiology, would also always produce some functional congealment of our experience, and this is its main function, fabricating by reduction identitary objects and practical orientations to the realization of our need of operating on the world and others. But this historiological aspect, which culminates with historical science and results in the formation of technologies of identity, orientation, historical entertainment and others, does not exhaust our need of history nor does it explain the totality of phenomena of historical representation and presentation (ARAUJO 2012).

Even in the historical discourse oriented by scientific standards, we often perceive elements smuggled from forms of experience other than pragmatic-scientific. In making this discourse its object of analysis, the history of historiography has broadened our ability to identify some of these 'smugglings', but has reached an impasse concerning the effects of these discoveries in the historiological project, that is, of historical science and technology. On the one hand, there are those who expect a purification and liberation from forces undermining the progress of scientific discourse; on the other hand, those who, assuming a radical criticism of this discourse, affirm what would be its seeming opposite, subjectivity as trust to a cognitive democracy, leading to the equivalence of all representations. It is obvious that these two pathways are two complementary sides of historiology without the capacity to go beyond the improper dimension of historicity. This structure that has just been described from Heidegger is also fundamental to Benjamin's and Koselleck's reflections about 'History'. Benjamin evidences that (1) a certain protagonist past determines the constitution of the present and that (2) certain maximally obscured pasts are related to certain presents in moments of 'peril', constituting the ideal conditions of possibility to the differentiation of time and 'History' (in the Jetztzeit, "now-time"), which, accordingly, opens new possibilities of projects, hopes and desires or even possible futures (BENJAMIN 2005; RANGEL 2011; 2013).

In Koselleck's case, the structure describing the movement of constitution, establishment and differentiation of 'History' is similar - the anthropological 
tension between 'spaces of experience' and 'horizon of expectation', which is also fundamental to understand a part of the works of Rüsen, who thinks from the categories of 'experience' and 'intention', and Hartog, with his 'regime of historicity' (HARTOG 2003; KOSELLECK 2006; RÜSEN 2001). For Koselleck, the 'space of experience' or a specific set of meanings and senses provided by certain pasts, and the 'horizon of expectation', a tendency toward projections, hopes and desires, cause tension within and from experiences of time and specific historical happenings resulting in differentiations and establishments of 'History'.

This structure is also fundamental to the thought of Hans Ulrich Gumbrecht from the category of 'fascination' (GUMBRECHT 1999; 2011). In other words, it is the anthropological need/possibility of projection, expectation or even desire, a fundamental structure also to what the author calls the necessity of men in general in relation to the material produced by historiography and the other ambits of historical culture. Moreover, it is the very relationship between this anthropological determination, fascination (the will to transcend birth also toward past worlds) and a certain contemporary conjuncture marked by a significant shortening of the future or of the 'horizon of expectation', which would explain or help to diagnose the 'chronotope' within which we find ourselves - that of the broad present or 'enlarged present'.

Berber Bevernage, on his turn, identifies the accelerated passage of the model of amnesia to that of memory and the right to truth as one of the effects of these broader transformations in the regime of modernist (or historicist)

340 historicity. In his evaluation, the crisis of modern consciousness of time and its politics of synchronization would render modernist practices of drawing away the past from the present less effective, the present being lived as a space occupied by an excess of traumatic memories (HARTOG 2003). In a context of excess of memory, the politics of amnesia becomes impracticable. For the modernist discourse, the deliberate destruction of a dead past could be seen as the acceleration of normal effects of a progressive time; with the crisis of this optimism, however, forgetting becomes more and more difficult. ${ }^{3}$

The presence of these anachronistic memories, from the point of view of the modernist discourse, makes the task of historical discourse of tracing a clear line between present and past increasingly difficult. Citing Primo Levi, Bevernage writes that the "memories of the offenses have continually grown since the Holocaust and now profoundly challenged the modern consciousness of time" (BEVERNAGE 2012, p. 465-466). We would then have a kind of collision between the attempt of modernist discourse to organize time linearly, attributing to the present the single centrality of presence, and the discourse of memory that insists on permanence and simultaneity.

Incapable of tracing a clear distinction between past and present, commissions of truth in post-traumatic societies would turn to history "[...] in order to pacify the troublesome force of 'memory.' History, then, is introduced in

\footnotetext{
3 "The problem with the past and the reason that it continues to torment, according to Ignatieff, is precisely that it is not past: 'Crimes can never be safely fixed in the historical past: they remain locked in the eternal present crying out for vengeance" (BEVERNAGE 2012, p. 441).
} 
the field of transitional justice not despite an already overabundant memory but because of it" (BEVERNAGE 2012, p. 493). The problem of commissions is no longer only that of establishing a historical consciousness through the treatment of memory; they become the stage whereon two distinct forms of memory are confronted - that of the irreversible past (historiography in the traditional sense) and that of the irrevocable past, that of victims. For the victims, the past has not passed and will not pass, and the living should take responsibility for this co-presence.

Still for Bevernage, modernist historiography would be based on the idea of the irreversibility of the past, its function being to distance it, to free societies of what Hayden White, in his famous article, called 'the burden of history' (BEVERNAGE 2012). Thus, we can understand the success of the constructivist formula that posits that the past would only exist insofar as it was (re)invented by the historian, providing present time with the exclusive privilege of the 'real' presence. Although he does not face this problem directly, Bevernage helps us to think by identifying how, in modernist historiography, the metaphysical concepts of subjectivity and memory would become central. In this world where everything is constructed, including the nation, 'only' the belief in the reality of the subjects would remain.

This way neo-historicist temporality can be better understood - 'History' is incessantly differentiating itself and it is up to the present, autonomous (almost independent), to build possible interpretations that are capable of reconstructing senses and provisional orientations, whether more subjectively or socially oriented. Thus, Hayden White, for instance, signals that there are maximally destabilizing happenings capable of provoking a radical disarticulation of the present, which would then render senses and suggestions provided by pasts inadequate. In thematizing the problem of the Holocaust and the 'final solution', the author affirms that $20^{\text {th }}$ century men (and also those of the $21^{\text {st }}$ century) would need to rebuild sets of meanings and of senses adequate to the inner existence of a world that would have questioned (almost) all morality and orientations proper to Western history. Yet, concerning the possibility of constituting enunciations that thematize this moment, it would be necessary to insist on a kind of 'free play' between memory and imagination in order for certain memories to be gradually faced and brought to light, which would have the power of (1) reorganizing language and morality and (2) producing (only) indicative and, thus, orienting knowledge. In this sense, we have a set of specific propositions by Hayden White concerning the method for gnoseological confrontation of radically critical moments. Although this method cannot be duly discussed in this space, there is already sufficient material to insert the thought of the North-America author within the linguistic turn, precisely in relation to the fundamental understanding that unites neo-historicist historians, namely that according to which the present is autonomous (almost independent) in relation to the past and has the task of reconstituting 'History' which, on its turn, is determined by the incessant and sometimes radically critical need of differentiation (WHITE 2003). 
Frank Ankersmitalso posits that there is no possibility of privileged relationship between thought and reality or between historiographical enunciations and the past due to the radical differentiation between past and present; the present ends up being a decisive ambit of resignification and reorganization of the past (ANKERSMIT 2001; 2012; ARAUJO 2006b). According to the author, if any privileged relationship between present and past has ever been possible (and this argument has an ironic sense), this was no longer possible since the production of works within history and historiography saw an increase, which would have enabled an even greater distancing between subject of knowledge and pasts investigated, since in (having to) go through these multiple interpretations, the historian would not have enough time for a significant approach in relation to the sources or he or she would already be determined by these readings. However, this reflection should not discourage researches in the field of history, since this impossibility of establishing privileged enunciations would enable history to participate, in a decisive manner, in its time, incessantly constituting and providing important understandings and judgments in relation to orientation.

\section{Reactions}

The texts published here, as well as the papers presented in our Seminar, also enable us to discuss the very repercussion of the linguistic turn or, yet, what would be its concrete developments within general historiography. In this sense, these repercussions should be sorted out due to the specificities of

342 historiographical cultures, but we highlight a problem we see as general, which could be called the ethical-political turn. Indeed, despite the historiographical culture or tradition in question (phenomenological-hermeneutic or neo-historicist), the reflections and understandings available from the linguistic turn point to the constitution of a common horizon within contemporary theory and history of historiography, namely (1) the subject of knowledge cannot produce privileged enunciations in relation to reality, despite the theories and methods being used and (2) historiography has a specific determination - that of thinking about and interceding in its world.

In spite of the arguments that can be used in favor or against this horizon, it seems that the contemporary world, after the linguistic turn, has become profoundly critical in relation to each and every argumentation founded on the possibility of producing privileged enunciations in relation to reality so that we can follow a certain consequence, more properly said general, of the linguistic turn within contemporary theory and history of historiography, namely its foundations or even its ethical-political justification (ethics meaning here thinking its own world; and politics, something such as a more ready and proactive intervention). In spite of the many differences concerning the reflections of contemporary authors such as Gumbrecht, François Hartog, Frank Ankersmit, Rüsen, Hayden White, Chris Lorenz, Marcelo Jasmim, Berber Bevernage, Luiz Costa Lima, Elias Palti, among others, the impression is that, due to the radical questioning and the loss of persuasive value of the justification - producing knowledge about the past -from the linguistic turn, contemporary theory and 
history of historiography have in the criterion of thinking about and intervening in the world, that is, in the ethical-political pretension, the determining point or even the main motive from which it insists (and justifies) thematizing the past within the present.

Authors such as Gumbrecht are concerned with the possibility of contemporary theory and history of historiography insisting in liberating pasts from what he calls the 'impossible realism' with the aim of broadening human sensibility, which means the possibility of provoking a more suitable relationship between sensibility, the always complex reality and the intellectual apparatus (GUMBRECHT 2011; 2014). It is in this sense that we can conceive of the problem of Stimmung as relevant to the reconstitution (intensification) of pasts. François Hartog is also concerned with the problem of a diagnosis of the contemporary world, which would be determined by a specific 'regime of historicity', that of 'presentism', so that the theory and history of historiography could be constituted as the ideal ambit to thematize this time, enabling the investigation of the motives responsible for what could be called an 'unbalanced' relationship between the present and certain pasts. For the French historian, the question lies on the fact that the $21^{\text {st }}$ century is still narrowly linked to the $20^{\text {th }}$ century, mainly from a sort of (perhaps) 'excessive' will of rethematization and reparation in relation to certain critical and traumatic historical happenings which apparently have not been addressed with due 'responsibility' since their occurrence. A possible reflection in relation to this problem could actually be made from the question of 'patrimonialism' (HARTOG 2006).

Rüsen highlights that the criterion of truth proper to the 'representation of continuities' has to be the force of rearticulation of certain pasts, reconsidered within the present or yet it is the very potency of orientation of historiographical narrative. Thus, the (fundamental) protocols typical of historical science would serve less to produce privileged enunciations than to constitute a maximally 'de-ideologizing' ambit, that is, ideal for a broader, more attentive and careful critique, able to decrease the persuasive power of individualizing understandings, which arise from politics, art, religion as well as from theory and history of historiography themselves. Frank Ankersmit signals that the very impossibility of producing privileged enunciations in relation to pasts enables a specific intervention of the theory and history of historiography in the present, because it provides a multiple and dynamic array of suggestions that may become suitable to the very movement of constitution (of differentiation and provisional stabilization) of 'History'.

Many are the paths and ambiguous the answers which can be found for this place of historiography as rigorous intellectual activity in our time. As authors such as Heidegger and Derrida point out, the very modern historical discourse tends to congeal the representation of the past as something simultaneously unstable and available. If each present produces its own history, we will always have more and more available histories, but this excess of histories fades away as soon as the very groundwork for this demiurgical self-centered present fades away within its concentrations. The present cannot ground the past and, at the same time, attempt to be grounded on this invented past. This vicious circle of 
modernism, frequently denounced, helps to understand the ambivalences of a world at the same time in need of and filled with pasts. The representations of the past available to us not only through historiography, but also though various sources and social actors (which we could call 'historic culture' from Rüsen) are not able to guide and open up the future, as well as they cannot help in thawing modern macro-representations. The great television productions, for instance, are ever more careful concerning material aspects of representation - clothing, sceneries; even social forms of reproducing life in Rome, in Renaissance Italy or in the Victorian Age, but the interpretive models, the implicit and explicit narratives remain fundamentally modern (delimited and hegemonic), which could also be affirmed, with some exceptions, for much of the scientific historiography produced. The history of liberal progress, defined by Hayden White as essentially comical-conciliatory, is still like the air we breathe in the public representations of history.

Finally, some reflections advanced by our Seminar and the texts published here should be presented: (1) some conditions of possibility of instauration and intensification of the linguistic turn from the $18^{\text {th }}$ and $19^{\text {th }}$ centuries, (2) two distinct traditions that have formed this epistemological movement, and (3) what we consider to be a general unfolding of the linguistic turn within contemporary theory and history of historiography, namely the exhaustion of autonomy and persuasive power of justification that historiography produces privileged knowledge about pasts and, thus, the past is thematized with the aim of knowing it (even if only partially) and even to guide us since we can know it. What is, then, unfolded from

344 what we call the ethical-political turn typical of the contemporary world is that the theory and history of historiography are becoming ideal ambits to thought and/ or to intervention in its time. And this is not because we can know the past and then think and intervene in our world, but actually because the thematization of the past in any ambit whatsoever of historical culture, including within the discipline of history, will always have the (necessary) power to mobilize men. It is ultimately a necessity grounded whether on the 'fascination' or on the 'historical consciousness', but always a necessity.

\section{Bibliographical References}

ANKERSMIT, Frank. A escrita da História: a natureza da representação histórica. Londrina: Eduel, 2012.

Historiografia e pós-modernismo. Topoi: revista de história, v. 2, p. 113-135, 2001.

ARAUJO, Valdei Lopes de. A aula como desafio à experiência da história. In: GONÇALVES, Márcia de Almeida et al. (orgs.). Qual o valor da história hoje? Rio de Janeiro: FGV, 2012.

. História da historiografia como analítica da historicidade. História da Historiografia, v. 12, p. 34-44, 2013.

Formas de ler e aprender com a História no Brasil joanino. Acervo, v.

22, p. 85-98, 2009. 
Observando a observação: sobre a descoberta do clima histórico e a emergência do cronótopo historicista, c. 1820. In: CARVALHO, José Murilo; CAMPOS, Adriana Pereira (orgs.). Perspectivas da cidadania no Brasil Império. Rio de Janeiro: Civilização Brasileira, 2011, p. 281304. v.1.

Para além da auto-consciência moderna: a historiografia de Hans Ulrich Gumbrecht. Varia História, v. 22, p. 314-328, 2006 a.

. Sobre o lugar da história da historiografia como disciplina autônoma. Locus, Juiz de Fora, v. 12, p. 79-94, 2006b.

BENJAMIN, Walter. Sobre o conceito de história. In: LÖWY, Michel. Aviso de incêndio: uma leitura das teses "Sobre o conceito de Historia". São Paulo: Boitempo, 2005.

BEVERNAGE, Berber. History, Memory and State-Sponsored Violence: Time and Justice. Routledge, 2012. (E-book).

CASANOVA, Marco Antonio. Compreender Heidegger. $4^{a}$ edição. Petrópolis: Vozes, 2013.

FOUCAULT, Michel. As palavras e as coisas: uma arqueologia das ciências humanas. São Paulo: Martins Fontes, 1999.

GUMBRECHT, Hans Ulrich. Atmosfera, ambiência, "Stimmung": sobre um potencial oculto na literatura. Rio de Janeiro: Constraponto/PUC-RJ, 2014. . Depois de "Depois de aprender com a história", o que fazer com o passado agora? In: NICOLAZZI, Fernando; MOLLO, Helena Miranda; ARAUJO, Valdei Lopes de (orgs.). Aprender com a história? O passado e o futuro de uma questão. Rio de Janeiro: Editora FGV, 2011.

. Em 1926: vivendo no limite do tempo. Rio de Janeiro/São Paulo: Editora Record, 1999.

. Modernização dos Sentidos. São Paulo: Editora 34, 1998.

HARTOG, François. Régimes d'historicité: présentisme et expériences du temps. Paris: Éditions du Seuil, 2003.

. Tempo e Patrimônio. Varia História, vol. 22, n 36, p. 261-273, jul/ dez, 2006.

HEIDEGGeR, Martin. Ser e Tempo. Petrópolis: Vozes; Bragança Paulista: Editora Universitária São Francisco, 2008.

Sein und Zeit. Tübingen: Max Niemeyer Verlag, 2006.

KOSELLECK, Reinhart. Futuro Passado: contribuição à semântica dos tempos históricos. Rio de Janeiro: Contraponto/PUC-Rio, 2006.

LYNCH, Christian Edward Cyril. Monarquia sem despotismo e liberdade sem anarquia: o pensamento político do Marquês de Caravelas. Belo Horizonte: Editora UFMG, 2014. 
RANGEL, Marcelo de Mello. Justiça e história em Derrida e Benjamin. Sapere Aude: revista de filosofia, v. 4, p. 347-359, 2013.

- O problema da ciência histórica em Friedrich Nietzsche e Walter Benjamin. Revista Urutágua, v. 23, p. 78-84, 2011.

. Romantismo, Sattelzeit, melancolia e "clima histórico" (Stimmung). Expedições: teoria da história e historiografia, v. 5, n. 1, 2014.

. Sobre a utilidade e desvantagem da ciência histórica, segundo Nietzsche e Gumbrecht. Dimensões, vol. 24, p. 208-241, 2010.

RANGEL, Marcelo de Mello; RODRIGUES, Thamara de Oliveira. História e Modernidade em Hans Ulrich Gumbrecht. Revista Redescrições, ano 3, n. 4, p. 63-71, 2012.

RÜSEN, Jörn. Razão Histórica. Teoria da história: os fundamentos da ciência histórica. Brasília: Editora Universidade de Brasília, 2001.

WHITE, Hayden. El Texto histórico como artefacto literario. Barcelona: Ediciones Paidós. I.C.E. de la Universidad Autónoma de Barcelona, 2003. 